\title{
EDITORIAL
}

\section{Illuminating informed consent}

About three years ago, a series of news stories about human experimentation with ionizing radiation during the 1940s, 1950s and 1960s raised the spectre of massive ethical abuse in the name of science and national security. Researchers working on the Manhattan Project allegedly injected hundreds of people with lethal doses of plutonium. Innocent children and pregnant women by the score were allegedly subjected to dangerous levels of radiation without their knowledge.

In response to claims that government scientists at the time were morally bankrupt, US president Bill Clinton did what presidents often do. He appointed a committee to study the secret history of radiation experiments that began in wartime and continued for two decades. Most important, he gave the committee full authority to probe previously classified military documents in order to fully reconstruct the radiation story.

Last month that committee released a remarkable report that illuminates both past and present. Having uncovered records of some 4,000 radiation experiments, the commission reported that there were, indeed, serious abuses, and concluded that some 30 individuals or their surviving relatives deserve compensation for injuries from ionizing radiation. Of equal interest, the committee found that the majority of human radiation studies were conducted by researchers who expressed great concern about the safety of the tests they were doing. Contrary to everyone's worst expectations, most of the research was scientifically justifiable and medically safe.

However, informed consent was, generally, no where to be found. As committee chair Ruth Faden, director of the Bioethics Institute at Johns Hopkins, noted, the radiation scientists were consumed by safety and oblivious to the idea that they seek consent from the patients on whom they were experimenting. A good deal of this can be attributed to the atmosphere of paternalism that permeated medicine and medical research until the late 1960 s and 1970s when attitudes toward the autonomy of human subjects began to change and the doctrine of informed consent gained moral prominence. Indeed, with respect to federally sponsored research, it was written into law.

From the outset, the radiation committee determined that it would not try to judge yesterday's research by today's standards. But it did ask this question: Could history in any way repeat itself vis-a-vis peoples' right to fully understand the risks and benefits of participating in a medical experiment?

The all-too-disturbing answer is an unambiguous 'Yes.' And it is here that the commission's careful research of a year and a half raises vital issues for future analysis and debate. A review of more than 100 randomly selected contemporary studies showed that patients may still be misled about experiments for which they volunteer.

Consent forms are too often written with a degree of technical detail that only serves to obfuscate or confuse. The following example is illustrative: The purpose of this study is to obtain a map of brain cholinergic receptors. ... This is done by administering, intravenously, small amounts of a radioactive substance that attaches to brain acetylcholine receptors and then producing a map of these receptors using Single Positron Emission Computed Tomography.' Got that?

In other cases, the committee discovered that consent forms explicitly or implicitly suggest a possibility of medical benefit that is not realistic, thereby enticing people to volunteer on the basis of false hope. The committee interviewed research patients at five medical centers and discovered that the majority by far favor research, trust the physician-scientists who are conducting the study, and believe that participating in a study may offer the last or only hope of recovery from terminal illness. That being so, presenting long-shot benefits realistically becomes all the more serious a moral obligation.

In this regard, it is pertinent that a significant percentage of the consent forms that were randomly selected for review got an ' $\mathrm{A}$ ' for presenting complex information clearly and explaining risks and benefits fully. In short, with the appropriate effort it can be done well. And it should be done.

The committee's landmark 925-page report is supported by thousands pages of documentation, that are available electronically to anyone who wants to see them (The address is http://www.seas.gwu.edu/nsarchive/ radiation.) The report of the Advisory Committee on Human Radiation Experiments should be read with care by everyone who is engaged in human medical experimentation of any kind. There is no excuse for ethical lapses in the treatment of research patients or healthy volunteers today and none should be tolerated.

Barbara J. Culliton 